\title{
Practice of Family Planning among Married Female Attendants to Shawa Family Health Unit, Dakahlia, Egypt
}

Nesrine Saad Farrag ${ }^{*}$, Aya Ahmed Fathy ${ }^{1}$, Farida AbdelWahab ${ }^{1}$

${ }^{1}$ Community Medicine Department, Faculty of Medicine, Mansoura University, Egypt.

\section{Abstract:}

Background: Contact of healthcare team with healthcare customers is a good opportunity to communicate health education regarding family planning (FP).

Objectives: to assess FP practice among rural female attendants to Shawa Family Health Center and to determine the associated factors. Methods: A cross-sectional study was conducted in Shawa village (Dakahlia governorate, Egypt). The target population included all married non-pregnant attendants during the period of the study. A predesigned questionnaire was used to collect data related to socioeconomic characteristics, FP practice, satisfaction with the service provided. A convenient sample was obtained.

Results: The study included 449 women. Contraception prevalence rate was $46.5 \%$. The prevalence of unmet need for limiting pregnancy was $23.8 \%$. Logistic regression shows that women's age of (25-34.9y), $\geq 35 \mathrm{Y}$, insufficient income, having more than 2 children were independent significant predictors of higher FP use [AOR (95\%CI): 7.8 (4.4-13.6), 1.4(0.7-2.8), 5.4(3-9.7), 2.4(1.3-4.3) respectively]. Among women aged $\geq 25 \mathrm{Y}$, the unmet need increased significantly among illiterate women [AOR $(95 \% \mathrm{CI}): 11.9(3.86-37.08)]$, while it decreased significantly among women with insufficient income [AOR $(95 \% \mathrm{CI})$ : 0.13(0.05-0.32)]. Important concerns related to privacy and counselling were documented. Conclusions: Findings showed poor FP practice among attendants. Contact of attendants with healthcare staff does not imply good FP practice if this contact is not accompanied by active communication and education. Poverty may be a trigger of higher FP practice. Unmet need for pregnancy limiting relates mainly to low education level. Information, Education, Counselling activities are urgently needed.

Keywords: Contraception maternal Care, primary healthcare, women's health, reproductive health,

\section{Introduction:}

Family planning (FP) is a vital primary Healthcare intervention that saves lives of mothers and infants, empowers women and supports their choices regarding their health, public life, and additional education. In addition, FP is considered as a short-term intervention to limit population growth and manage overpopulation problems. $^{(1)}$ Worldwide in 2017 , about $63 \%$ of women in reproductive age (15-49Y) were using some form of contraceptives, with a prevalence above $70 \%$ in most developed countries. In developing countries, there were 214 million women in need to avoid pregnancy, while they were not using any modern contraceptive method (i.e. unmet need for FP). This huge number may be due unavailable services, information, or lack of support from partners or community. Globally, the prevalence unmet need for FP was $12 \%$ in 2017 , and the rate was higher in Africa reaching 22\%. ${ }^{(2)}$

Egypt is the most populated country in the Middle East and the third most populated country in Africa. Since 1990, there was gradual decrease in the total fertility rate 
(TFR) in Egypt from 4.1 children per woman in 1991 to 3.0 in 2008 , but unexpectedly, it increased to 3.5 during 2014. ${ }^{(3)}$ Egypt did not achieve Millennium Development Goals (MDG) 2015 target which was aiming at a contraceptive rate of $70 \%$ to achieve TFR of 2.1 children per woman by the year 2017 . According to United Nations Development Program in 2015 , CPR ranged from $59 \%$ to $60 \%$, during the previous 10 years with significant geographical differences. ${ }^{(4)}$

In Egypt, while physical and administrative factors play insignificant role in shaping patterns of FP practice. ${ }^{(5)}$ Certain socio-demographic, cultural, and reproductive factors act as barriers that limit FP use, increase discontinuation rates and increase the unmet need of FP. (5),(6) Identifying these barriers helps guide policy and decision makers determine where efforts should be directed to promote efficiency of the FP services. ${ }^{(7)}$

Family planning service quality has been studied widely as an important target for improvement to increase acceptance and utilization and of FP service. ${ }^{(8)}$ Training healthcare providers to provide a clientcentered FP service including expanded contraceptive method choices and comprehensive effective accurate counselling is an important aspect of improving the quality of the service, which undoubtedly, improve clients' satisfaction. ${ }^{(9)}$ United Nations population Fund is partnering with reproductive health sector of the Egyptian Ministry of health $(\mathrm{MOH})$ to expand family planning use especially long acting methods to help decrease total fertility rate. The cooperation includes strengthening the contraceptive system, capacity building of the MOH personnel, advocacy targeting multiple stakeholders, training of nurses, targeting weak points in the contraceptive system through research for closing gaps in the systems. $^{(10)}$

Egyptian Government provides contraceptive methods through Health Units services with very low price in Urban and Rural areas. The CPR varies widely across Egypt regions. It is reported that Urban women were more likely to be using contraceptives than rural women. ${ }^{(3)}$ Utilizers of Family Health Units' (FHU) services have more contact with healthcare team. Consequently, they have more chance to receive health education and counseling regarding family planning.

The current study aimed to achieve the following objectives:- 1- Determine the Contraceptive prevalence rate (CPR), the 
unmet need for pregnancy limiting among married female attendants of Shawa Family Health center (SFHC), a rural center. 2. Determine the associated factors with FP use and unmet need for FP (pregnancy limiting).3. Assess satisfaction of women with FP service provided at SFHC.

\section{Methods:}

Study design: A cross-sectional healthcare center-based study

Location of the study: The study was conducted in Shawa village, Mansoura district, Dakahlia, Egypt. According to SFHC records (2017), the village is inhabited by 17.157 persons (4022 families). The main profession of the inhabitants is cultivation and minorities are employees.

The target population included any currently married woman in the child bearing age (1549Y) using SFHC health services. Women who were divorced, widowed or beyond age of fertility were excluded. The researchers visited SFHC two days per week for interviewing women about their FP experience after their exit from different clinics. After explaining the aim of the study and assuring confidentiality, informed written consent was obtained from every woman who accepts to participate in the study. In case of illiteracy, verbal consent was obtained.
Sample size: Recruitment of participants extended from Marsh 2017 to end of August 2017. A convenient sample included, in total, 449 women.

Study tool: A predesigned validated questionnaire, especially developed for this study, was used for interviewing women. The questionnaire included three main sections;

1. Socio-demographic characteristics of participating women as age, education of the mother and her partner, mothers' working status, fathers' occupation, family income according to Fahmy et al.'s (2015) socio-economic scoring system ${ }^{(11)}$,

2. Family planning practice: This included number of living children, current use of FP method and its type, planning for future pregnancy, suggested duration before next pregnancy, and suggested causes of discontinuation of FP,

3. Women's satisfaction with FP service provided at SFHC: The aspects assessed were; accessibility of the site, suitability of waiting time, comfortability of waiting area, welcoming the woman politely, easily understandable information given during the counseling, respect of privacy during counselling and receiving FP service, available educational material (brochures, books...etc.), respect of 
woman FP method choice, affordable price of FP method, women's preference of currently FP method they use, women were asked if they were satisfied.

The second and third sections were derived from a United Nations Population Fund (UNPF) questionnaire ${ }^{(12)}$. The questionnaire was shortened to include the main questions specific to our study aims., then it was translated to Arabic and back-translated to English by two different experts to ensure linguistic validity of the questionnaire.

Content validity of the questionnaire was assessed by a gory of 5 public health experts. A pilot study was conducted on 20 women for training the investigators on collecting data and for testing the questionnaire, with respect to clearness, and easy understandability. Modifications were done accordingly. The pilot study cases were not included in results of the study.

Statistical analysis of data: The collected data was organized, tabulated and statistically analyzed using statistical package for social science (SPSS) version 16. Frequencies and proportions were used to present FP rates. Univariate analysis (using Chi square tests) was conducted to determine significant predictors of FP use, unmet need for FP. Multivariate logistic regression was done to underline significant independent predictors of FP use and unmet need for FP (pregnancy limiting). Because the problem of unmet need was found to be, mainly, a problem of women aged $\geq 25 \mathrm{Y}$, the logistic regression of unmet need included only these women. The significance level was set at $\mathrm{p}<0.05 \%$.

Ethical considerations: The research procedures were conducted in accordance with the principles of Declaration of Helsinki. An informed written consent was obtained from each participant in the study. In case of illiteracy, informed oral consent was obtained. This study was approved by Research Ethical Committee of Faculty of Medicine (Mansoura University) [CODE NO R.18.12.374]. Also, it was approved by health authorities and managers of SFHC after explaining objectives and procedures of the study, in order to get the approval and cooperation throughout the study.

\section{Results:}

This study included 449 currently married women who attended SFHC and accepted to participate in the study. One third of participants were below 25Y, 90.9\% were not employed, and 57\% completed secondary schools' education, and nearly $76 \%$ of participants have enough income (not presented in table). 
Table (1) shows that $46.5 \%$ of the studied women were currently FP users. The most commonly used methods were IUD (25.8\%), followed by Pills (11.4\%), injectable methods $(4.9 \%)$, condom $(2.7 \%)$, and others $(1.7 \%)$. Only $26.5 \%$ of women wanted to gain future pregnancy. Pregnancy spacing should be less than 3 years, according to $60.6 \%$ of women. Desire for pregnancy was the most commonly cited cause (64.1\%) to discontinue FP, followed by bleeding (12\%), frequent forgetting (9.5\%), and method failure (5.5\%). Bleeding and method failure were more commonly reported by IUD users, while forgetting was more commonly reported by Pills users.

FP use is higher among women aged 25$34.9 \mathrm{Y}$ and $\geq 35 \mathrm{Y}$ compared to women aged $<25 \quad(\mathrm{OR} \quad(95 \% \quad \mathrm{CI}): \quad 7.1(4.3-11.6)$, 2.4(1.4-4.07)), women with insufficient income (OR (95\% CI): 3.7(2.2-6.12)), and women with more than 2 children (OR (95\% CI): 2.21(1.49-3.26)). FP use is lower among and among non-working women (OR (95\% CI): 0.47 (0.24-0.91)) (Table 2).

Results shows that 247 (55\%) women did not want future pregnancy, of them, $31.2 \%$ $(n=140)$ used some form of FP, while $23.8 \%$ $(n=107)$ were nonusers (i.e. unmet need for limiting pregnancy). Unmet need for pregnancy limiting was mainly a problem of women aged 25Y (Table 3). Unmet need was higher among non-working women (OR:95\% CI, 3.12:1.1-8.98), illiterate women (OR (95\% CI): $7(2.72-18)$ ), wives of manual workers (OR (95\% CI): 2.5(1.3-5)). Unmet need was lower among women with insufficient income (OR (95\% CI), 0.37(0.19-0.73).

Multiple regression shows that women's age of $(25-34.9 y)$ and $\geq 35 Y$, insufficient income, and having more than 2 children are independent significant predictors of higher FP use (adjusted OR: 7.8, (95\% CI) (4.413.6), $1.4(0.7-2.8), \quad 5.4(3-9.7), \quad 2.4(1.3-4.3)$ respectively) (Table 4). Among women aged $\geq 25 \mathrm{Y}$, illiteracy increased unmet need for pregnancy limiting 11 times (adjusted OR: $11.9, \quad(95 \% \quad$ CI $) \quad(3.86-37.08)), \quad$ while insufficient income significantly decreased unmet need (adjusted OR: 0.13 (95\% CI) $(0.05-0.32))$.

Aspects of women satisfaction with their FP service experience at SFHC were shown in table (5), where more than $90 \%$ of them are satisfied with most aspects under question. Worthy of note, is that $100 \%$ of users reported that service is affordable. The main concerns were related to the process of counselling, as only $67.5 \%$ understood the information given during counselling, while 
$8.1 \%$ reported that no information was given. Only $63 \%$ of them reported that they felt privacy. Only $1.9 \%$ of women reported availability of educational notes or materials about FP.

\section{Discussion:}

Overall, $46.5 \%$ of attendants of SFHU are currently using a FP method. This rate is much lower than the national CPR (57\%) among rural women reported by the last national household survey (EDHS 2014). ${ }^{(3)}$ Also it is lower than the rates reported by other Egyptian studies in rural area of Fayoum ( $61 \%)^{(13)}$ and Minia $(54 \%){ }^{(14)}$

The CPR in our study is much higher than some African countries as Cameroon $(21 \%$ in 2014), Chad (5\% in 2015), Ghana (33\% in 2017), Ethiopia (35.2\% in 20017), Nigeria (13.4\% in2017) but it was lower than some countries as Jordan (61.2\% in 2012), Bangladesh (53.9\%in 2014), Malaysia 52.2\% (2014), and India (54.5\% in 2016). All these rates and the rate of the current study are low in contrast with studies in most developed countries for example, Norway $(88.4 \%$ in 2005), United Kingdom (84\% in 2008), France $78.4 \%$ (2011) and Finland (85.5\%in 2015). ${ }^{(15)}$

Family planning practice is a multifaceted behavior that needs working in many direction for improvement. ${ }^{(2)}$ Generally, low prevalence rates of contraception use may be due unavailable or inaccessible FP services. But the Egyptian Government provides contraceptive methods through FHUs for a very low price in Urban and Rural areas. In the current study, the low CPR may be attributed to low literacy, some prevailing traditional believes that constitute the social norms (e.g. son preference and having more children for larger and strong families), lack of women's knowledge of benefits of FP and women reproductive health. Above all, worsening in the role of health services in raising awareness in this rural society has its share in the problem.

Conducting the current study among attendants of a healthcare center, we argued at the start of the research that we would find a CPR higher than the general rate among rural women reported by EDHS (2014). But, on the contrary, we found a much lower rate which means missed opportunities for the healthcare staff to contact these women to encourage and educate about the benefits of FP. Increasing demand to contraception is an important aspect of strong FP programs to increase CPR and hopefully, decreasing fertility rate. ${ }^{(2)}$

This study showed that IUD and pills were the most widely used methods. The same 
was reported by EDHS 2014 (3). Another Egyptian study reported that injectables (16 $\%)$ are more common than pills $(7 \%){ }^{(13)} \mathrm{A}$ recent study in Minia, Upper Egypt, reported that injections were the most frequently everused methods. ${ }^{(14)}$ Preference of contraceptive methods varies widely among different communities, for example in Bangladesh, using pills was the most common method (nearly 27\%) and IUD was the least prevalent method (nearly $1 \%$ or less). (16) In Pakistan, where low rates of FP use were reported (around 20\%), the most common method was condom (nearly 6\%), followed by injections (nearly $2.5 \%){ }^{(17)}$

Many reasons may force the women to use one method or another. Among these reasons, are perceived effectiveness, permanence, long-term effectiveness, quality, and affordability. Also, availability, easy access and use of contraceptive method have their share in affecting choice of the method. (17) Fear of complications of other methods is an important determinant. ${ }^{(13)}$ Worldwide, IUD and female sterilization were the most prevalent contraceptive methods, according to United Nations report (2015). The dominance of a single method in a country may be referred to the deficient access to a full range of contraceptive methods, and dependence on certain institutions that provide a limited set of methods. However, this is not a concern, if less effective methods are replaced by more effective ones. ${ }^{(18)}$

Continuity of contraception usage is vital to avoid unwanted births. The most commonly suggested cause of FP discontinuation was desire for pregnancy (64.1\%). Bleeding was reported more among IUD and injectables users, while forgetting the method was reported mainly among pills users, and method failure was reported more among IUD users. The actual causes of contraceptive discontinuation within 12 month of FP method use were assessed by EDHS (2014). The report indicated that for all contraceptive methods the desire of pregnancy was the main cause for discontinuity of FP use but with lower rate $(36 \%)$, side effect of the method was responsible for $29 \%$ of discontinuity and $8.8 \%$ due to infrequent $\operatorname{sex} .^{(3)}$

Socioeconomic factors had been extensively studied to explore how they modify FP practice in different communities. Our results went in line with results of EDHS 2014, which showed that women's age, employment, family size, and income had substantial effect on FP use, while women's education had minimal effect on FP use. ${ }^{(3)}$ 
Age of women is one of the frequently cited factors that predict FP practice. Consistently, FP use is lower among younger women. (17),(19), (20) Our results also went in line with Islam et al. who found that highest contraceptive rate among Bangladesh women was among women aged 25-34Y.(16) This difference is because younger and older women are generally less interested in using FP methods, as younger women did not have the desired number of children yet, while infrequent sex and onset of menopause may be the causes in older women.

As expected, the problem of unmet need for limiting pregnancy occurred mainly in older women. Women aged $\geq 35 \mathrm{Y}$ used FP nearly twice FP use among women aged $<25 \mathrm{Y}$. Yet, this rate is not enough to meet their need for limiting pregnancy. Patra et al. found that the factors affecting FP practice are different across different age categories and they argued that FP strategies should be tailored according to requirements of each category. ${ }^{(20)}$

Economic status has been consistently identified as one of the key factors affecting contraceptive use and its pattern. Most studies found that FP use increased significantly with higher economic status of women. ${ }^{(17)(21)(20)}$ In our study income was independent significant predictor of FP use. Mothers having a high income to save, and women with insufficient income (i.e. extremities) were significantly more FP users, because they resort to have less children for advancement of their social welfare or economic status. Women with justenough income, most probably, believe that contraception will reduce their family labor size.

Women's education empowers them giving them more control over their health choices and increases their health knowledge. Higher education predicted higher FP use in different studies. ${ }^{(17)(21)(20)}$ On the other hand, Hussain found that literacy was not associated with FP use at all ${ }^{(19)}$, while Islam et al. found that education was a significant predictor among unemployed women, not employed women. ${ }^{(16)}$ In our study, education level of women was not associated with FP use, but it was a significant predictor of unmet need for pregnancy limiting among women aged $\geq 25 \mathrm{Y}$ together with their income. This clearly indicates how important is the role of family planning system to contact these women to increase their awareness and improve such problem through education information counselling activities (EIC). ${ }^{(10)}$

Number of living children is an important factor that affects FP practice. Our study indicated that number of living children 
was a significant independent predictor of FP use. It was reported by many studies to be positively associated with FP use. ${ }^{(3,17,21)}$ Hussain et al. argued that it is not the number of living children which affected FP use. Rather, it is the number of living sons which affected FP use, due to son preference. ${ }^{(19)}$

Availability and easy access to contraceptive have an important role in affecting the practice FP. ${ }^{(17)}$ More than $90 \%$ of women were satisfied with most aspects of the FP service. The reported shortcomings were related to privacy of women during receiving the service, and the unavailability of educational materials (only $1.9 \%$ reported exposure to such materials). Also, the communication skills of providers were questionable, where substantial proportions of women either did not receive any information, or did not understand the given information during counselling.

Satisfaction with FP service, provided at family health centers, in Egypt was studied in other studies ( Assiut City, and Port-Said city), which agreed to the high satisfaction rate among utilizers of the service. ${ }^{(22),(23)}$ However, Mohamed et al. recommended training of providers to improve their communication skills. ${ }^{(22)}$ Nasr et al. found a significant association between training of health care providers and satisfaction of women with FP service. $^{(23)}$

Limitations of the study: The study is not a household survey to report a general prevalence in the studied village. However, that was an aim of the study to assess to what extent contact with health services had affected FP practice among the attended women. Assessing customers' satisfaction within the health facility may involve courtesy bias, as women may refrain from criticizing the facility from which they receive the service. Also, recall bias may affect women's answers to some questions. The study did not include unmet need for pregnancy spacing.

Conclusions: Findings showed poor FP practice among attendants. The CPR among attendants of SFHC was lower (46.5\%) than the general CPR among rural population in Egypt. Also, the unmet need for limiting pregnancy was higher $(238 \%)$ than the general prevalence. Contact of attendants with healthcare staff does not imply good FP practice if this contact is not accompanied by active communication and education. Poverty was a trigger of higher FP practice. The unmet need for limiting pregnancy is mainly a problem among illiterate women.

The current study showed satisfaction of women with the service provided except for 
important drawbacks related to communication and privacy. Although the results cannot be generalized to all FHCs, similar results could be obtained from studying many other rural centers. Family health centers are missed opportunities to increase FP use in rural areas of Egypt.

Recommendations: Wide Information, Education, Counselling (IEC) activities are needed to increase demand to FP services and satisfy unmet need for FP. Improvement in the communication skills of providers, together with good supervision of the health centers are vital for strengthening of FP system. Educational materials should be available for better counselling. Privacy during providing FP service should be monitored and improved. Encouraging higher education among girls is very important to increase and encourage the family planning use in such rural areas. Further research is required to investigate causes of unmet needs of FP.

Funding: This research did not receive any grant from funding agencies in the public, commercial, or not-for-profit sectors.

Competing Interests: The authors declare that they have no conflicts to disclose.

\section{References:}

1. World Health Organization. WHO Postpartum family planning: essential for ensuring health of women and their babies [Internet]. WHO. World Health Organization; 2018 [Accessed 2018 Oct 30] Available from: http://www.who.int/reproductivehealth/to pics/family_planning/worldcontraception-day-2018/en/

2. United Nations Department of Economic and Social Affairs. World Family Planning 201-Highlights [Internet]. New York; 2017 [Accessed 2018 Dec 19]. Available from: http://www.un.org/en/development/desa/ population/publications/pdf/family/WFP2 017 Highlights.pdf

3. El-Zanaty F, Way A. Egypt Demographic and Health Survey 2014 [Internet]. Cairo, Egypt: Ministry of Health and Population and ICF International; 2015 [Accessed 2017 Sep 6]. Available from: https://www.unicef.org/egypt/eg_Edhs_e n.pdf

4. United Nations Development Program (UNDP); the Ministry of National Planning. Egypt's Progress towards Millennium Development Goals [Internet]. Cairo; 2015 [Accessed 2018 Nov 27]. Available from: http://www.printright.biz/

5. Eltomy EM, Saboula NE, Hussein a a. 
Barriers affecting utilization of family planning services among rural Egyptian women. East Mediterr Heal J [Internet]. 2013;19(5):400-8.

6. El-Masry R, Essam N, Ghoneim M. Unmet need for family planning among women in rural Egypt. Int J Community Med Public Heal [Internet]. 2018 Mar 23 [cited 2018 Dec 18];5(4):1252.

7. El-Zanaty F, Way A. Egypt Demographic and Health Survey 2008 [Internet]. Cairo. Cairo, Egypt: Ministry of Health and Population and ICF International; 2009 [cited 2017 Oct 12].

8. Fruhauf T, Zimmerman L, Kibira SPS, Makumbi F, Gichangi P, Shiferaw S, et al. Measuring family planning quality and its link with contraceptive use in public facilities in Burkina Faso, Ethiopia, Kenya and Uganda. Health Policy Plan [Internet]. Oxford University Press; 2018 Sep 1 [cited 2018 Dec 22];33(7):828-39.

9. Clark H, RamaRao S, Unthank C, Machiyama K, Thatte N. Family Planning Evidence Brief - Expanding contraceptive choice [Internet]. Geneva; 2018 [Accessed 2018 Dec 20]. Available from:

http://apps.who.int/iris/bitstream/handle/1
0665/255865/WHO-RHR-17.14-

eng.pdf? sequence $=1$

10. United Nations Population Fund. UNFPA Egypt | Family planning [Internet]. 2018 [cited 2018 Dec 18]. Available from: https://egypt.unfpa.org/en/node/22543

11. Fahmy SI, Nofal LM, Shehata SF, El Kady HM, Ibrahim HK. Updating indicators for scaling the socioeconomic level of families for health research. J Egypt Public Health Assoc [Internet]. 2015 Mar [cited 2017 Oct 10];90(1):1-7.

12. United Nations Population Fund. An Approach to monitoring Quality of Care in Turkey's Family Planning Programme | UNFPA - United Nations Population Fund [Internet]. 2010 [Accessed 2018 Dec 11]. Available from: https://www.unfpa.org/resources/approac h-monitoring-quality-care-turkeysfamily-planning-programme

13. Ragab WS, Abdelwahid WY. Contraception Use among Parous Egyptian Women Attending an Antenatal Clinic. Med J Cairo Univ [Internet]. 2014;82(2):47-53.

14. Eshak ES, Sayed SI, Kamel EG, ElSheref MA. Non-medical predictors for ever and current use of contraceptives among women in Minia, Upper Egypt. J 
Public Health (Bangkok) [Internet].

Springer Berlin Heidelberg; 2018 Dec 27

[cited 2019 Jan 10];26(6):663-71.

15. United Nations Population Division

Department of Economic and Social Affairs. World Contraceptive Use 2018 [Internet]. 2018 [Accessed 2018 Dec 22]. Available from: http://www.un.org/en/development/desa/ population/publications/dataset/contracep tion/wcu2018.shtml

16. Islam AZ, Mondal MNI, Khatun ML, Rahman MM, Islam MR, Mostofa MG, et al. Prevalence and Determinants of Contraceptive use among Employed and Unemployed Women in Bangladesh. Int J MCH AIDS [Internet]. Global Health and Education Projects, Inc.; 2016;5(2):92102.

17. Azmat SK, Ali M, Ishaque M, Mustafa G, Hameed W, Khan OF, et al. Assessing predictors of contraceptive use and demand for family planning services in underserved areas of Punjab province in Pakistan: results of a cross-sectional baseline survey. Reprod Health [Internet]. BioMed Central; 2015 Mar 28 [cited 2019 Jan 7];12:25.

18. Trends in Contraceptive Use Worldwide 2015 [Internet]. New York; 2015
[Accessed 2019 Jan 12]. Available from: http://www.un.org/en/development/desa/ population/publications/pdf/family/trends ContraceptiveUse2015Report.pdf.

19. Hussain N. Demographic, SocioEconomic and Cultural Factors Affecting Knowledge and Use of Contraception Differentials in Malda District, West Bengal. J Community Med Health Educ [Internet]. OMICS International; 2011 Nov 18 [cited 2018 Dec 23];0(01):1-10.

20. Prata N, Bell S, Weidert K, NietoAndrade B, Carvalho A, Neves I. Varying family planning strategies across age categories: differences in factors associated with current modern contraceptive use among youth and adult women in Luanda, Angola. Open access $\mathbf{J}$ Contracept [Internet]. Dove Press; 2016 [cited 2019 Jan 4];7:1-9.

21. Kanwal Aslam S, Zaheer S, Qureshi MS, Aslam SN, Shafique K. Socio-Economic Disparities in Use of Family Planning Methods among Pakistani Women: Findings from Pakistan Demographic and Health Surveys. PLoS One [Internet]. Public Library of Science; 2016 [cited 2019 Jan 2];11(4):e0153313.

22. Mohamed SA, Mohamed AG, Arief AF. Women Satisfaction with Family 
Planning Services in Maternal and Child

Health Centers, Assiut City, Egypt. Am J

Nurs Res [Internet]. Science and

Education Publishing; 2017 Aug 26

[cited 2019 Jan 13];5(3):79-85. between quality of family planning services and client's satisfaction level in maternal and child health centers in Port Said city. J Nurs Educ Pract [Internet]. 2015 Oct 19 [cited 2019 Jan 13];6(1):85.

23. Nasr EH, Hassan HE. Association

Table (1): Family planning (FP) practice among married women $(\mathrm{N}=449)$

\begin{tabular}{|c|c|c|c|}
\hline Attribute & & No & $\%$ \\
\hline Current use of FP & & 209 & 46.5 \\
\hline \multirow[t]{5}{*}{ Methods used for FP } & IUD & 116 & 25.8 \\
\hline & Pills & 51 & 11.4 \\
\hline & Injectable & 22 & 4.9 \\
\hline & Condom & 12 & 2.7 \\
\hline & Other & 8 & 1.7 \\
\hline \multirow[t]{3}{*}{ Desire in future pregnancy } & No* & 247 & 55 \\
\hline & Yes & 119 & 26.5 \\
\hline & Not know & 83 & 18.5 \\
\hline \multirow[t]{3}{*}{ Suggested Duration of pregnancy spacing } & $1-<3$ years & 272 & 60.6 \\
\hline & $3-5$ years & 166 & 37 \\
\hline & $>5$ years & 11 & 2.4 \\
\hline \multirow[t]{5}{*}{$\begin{array}{l}\text { Suggested causes of discontinuation of } \\
\text { contraception use (209) }\end{array}$} & $\begin{array}{l}\text { Desire for } \\
\text { pregnancy }\end{array}$ & 134 & 64.1 \\
\hline & Bleeding & 25 & 12 \\
\hline & Forget & 20 & 9.5 \\
\hline & Method failure & 11 & 5.3 \\
\hline & Others & 19 & 9.1 \\
\hline Unmet need of FP (for birth limiting) * & & 107 & 23.8 \\
\hline
\end{tabular}

*107 women, of 247 women who did not want future pregnancy, did not use any method of FP 
Table (2): Predictors of Family planning (FP) use among married women7 (N=449)

\begin{tabular}{|c|c|c|c|c|c|c|c|}
\hline \multirow{2}{*}{\multicolumn{2}{|c|}{ Predictors }} & \multirow{2}{*}{$\begin{array}{l}\text { Total } \\
\text { No }\end{array}$} & \multicolumn{2}{|c|}{ FP Users } & \multirow[t]{2}{*}{ OR (95\%CI) } & \multirow[t]{2}{*}{$\mathrm{X}^{2}$} & \multirow[t]{2}{*}{ P value } \\
\hline & & & No & $\%$ & & & \\
\hline \multicolumn{2}{|l|}{ Overall } & 449 & 209 & 46.55 & & & \\
\hline \multirow[t]{3}{*}{ Age } & $<25$ & 145 & 34 & 23.4 & $\mathrm{r}(1)$ & & \\
\hline & $25-34.9$ & 177 & 121 & 68.4 & 7.1(4.29-11.6) & 64.402 & $<0.001 *$ \\
\hline & $\geq 35$ & 127 & 54 & 42.5 & $2.42(1.43-4.07)$ & 11.25 & $0.001 *$ \\
\hline \multirow[t]{2}{*}{ Work } & Yes & 41 & 26 & 63.4 & $\mathrm{r}(1)$ & & \\
\hline & No & 408 & 183 & 44.9 & $0.47(0.24-0.91)$ & 5.159 & $0.023 *$ \\
\hline \multirow[t]{4}{*}{ Education } & Illiterate/literate & 84 & 40 & 47.6 & $\mathrm{r}(1)$ & & \\
\hline & Primary & 38 & 22 & 57.9 & $1.5(0.7-3.28)$ & 1.105 & 0.293 \\
\hline & Secondary & 256 & 113 & 44.1 & $0.87(0.53-1.43)$ & 0.309 & 0.578 \\
\hline & University & 71 & 34 & 47.9 & $1.011(0.54-1.9)$ & 0.001 & 0.973 \\
\hline \multirow{3}{*}{$\begin{array}{l}\text { Occupation } \\
\text { of the } \\
\text { husband }\end{array}$} & Manual & 311 & 139 & 44.7 & $\mathrm{r}(1)$ & & \\
\hline & Commerce & 54 & 26 & 48.1 & $0.87(0.48-1.55)$ & 0.221 & 0.638 \\
\hline & Professional/empl & 84 & 44 & 52.4 & $0.73(0.45-1.19)$ & 1.571 & 0.209 \\
\hline \multirow{3}{*}{$\begin{array}{l}\text { Family } \\
\text { income }\end{array}$} & Enough & 342 & 133 & 38.9 & $\mathrm{r}(1)$ & & \\
\hline & Not enough & 87 & 61 & 70.1 & $3.69(2.22-6.12)$ & 27.3 & $<0.001 *$ \\
\hline & Save & 20 & 15 & 75.0 & $4.71(1.67-$ & 0.189 & $0.001 *$ \\
\hline \multirow{2}{*}{$\begin{array}{l}\text { No of living } \\
\text { children } \\
(\mathrm{N}=447)\end{array}$} & $1-2$ children & 281 & 111 & 39.5 & $\mathrm{r}(1)$ & & \\
\hline & $>2$ children & 166 & 98 & 59 & $2.21(1.49-3.26)$ & 15.99 & $<0.001^{*}$ \\
\hline
\end{tabular}

$\mathrm{X}^{2}$ : chi square, OR: Crude Odds Ratio, CI: confidence interval, $\mathrm{r}=$ reference group 
Table (3): Predictors of unmet need of Family planning among married women $(\mathrm{N}=449)$

\begin{tabular}{|c|c|c|c|c|c|c|c|}
\hline \multirow{2}{*}{\multicolumn{2}{|c|}{$\begin{array}{l}\text { Predictors } \\
\end{array}$}} & \multirow[b]{2}{*}{ Total } & \multicolumn{2}{|c|}{ Unmet } & \multirow[t]{2}{*}{ OR (95\%CI) } & \multirow[t]{2}{*}{$\mathbf{X}^{2}$} & \multirow[t]{2}{*}{ P value } \\
\hline & & & No & $\%$ & & & \\
\hline \multicolumn{2}{|l|}{ Overall } & 449 & 107 & 23.8 & & & \\
\hline \multirow[t]{3}{*}{ Age } & $<25$ & 145 & 4 & 2.8 & $\mathrm{r}(1)$ & & \\
\hline & $25-34.9$ & 177 & 34 & 19.2 & $8.3(2.9-24.2)$ & 20.723 & $<0.001^{*}$ \\
\hline & $\geq 35$ & 127 & 69 & 54.3 & $41.9(14.6-120.2$ & 91.705 & $<0.001 *$ \\
\hline \multirow[t]{2}{*}{ Work } & Yes & 41 & 4 & 9.8 & r (1) & & \\
\hline & No & 408 & 103 & 25.2 & $3.1(1.1-8.9)$ & 4.924 & $0.026^{*}$ \\
\hline \multirow{4}{*}{$\begin{array}{l}\text { Education of } \\
\text { women }\end{array}$} & University & 71 & 6 & 8.6 & $\mathrm{r}(1)$ & & \\
\hline & Secondary & 256 & 61 & 23.8 & $3.4(1.4-8.3)$ & 8.07 & $0.005^{*}$ \\
\hline & Primary & 38 & 7 & 18.4 & $2.45(0.8-7.9)$ & 2.342 & 0.126 \\
\hline & Illiterate/literate & 84 & 33 & 39.3 & $7(2.7-18.02)$ & 19.428 & $<0.001 *$ \\
\hline \multirow{3}{*}{$\begin{array}{l}\text { Occupation of } \\
\text { the husband }\end{array}$} & Professional/employee & 84 & 11 & 13.1 & $\mathrm{r}(1)$ & & \\
\hline & Manual & 311 & 86 & 27.7 & $2.5(1.3-5.01)$ & 7.565 & $0.006^{*}$ \\
\hline & Commerce & 54 & 10 & 18.5 & $1.5(0.6-3.8)$ & 0.749 & 0.387 \\
\hline \multirow[t]{3}{*}{ Family income } & Enough & 342 & 96 & 28.1 & r (1) & & \\
\hline & Not enough & 87 & 11 & 12.6 & $0.37(0.2-0.7)$ & 8.817 & $0.003 *$ \\
\hline & Save & 20 & 0 & 0 & undefined & 7.64 & $0.005^{*}$ \\
\hline \multirow{2}{*}{$\begin{array}{l}\text { No of living } \\
\text { children }(\mathrm{N}=\mathbf{4 4 7})\end{array}$} & $1-2$ children & 281 & 41 & 14.6 & $\mathrm{r}(1)$ & & \\
\hline & $>2$ children & 166 & 65 & 39.2 & $3.7(2.4-5.9)$ & 34.812 & $<0.001 *$ \\
\hline
\end{tabular}

$\mathrm{X}^{2}$ : chi square, OR: Crude Odds Ratio, $\mathrm{CI}$ : confidence interval, $\mathrm{r}=$ reference group 
Table (4): Multivariate logistic regression of predictors of family planning use and unmet need for family planning among married women $(\mathrm{N}=449)$

\begin{tabular}{|c|c|c|c|c|c|c|c|}
\hline \multirow{2}{*}{\multicolumn{2}{|c|}{ Predictors }} & \multicolumn{3}{|c|}{$\begin{array}{l}\text { Family planning use } \\
\qquad(\mathrm{N}=449)\end{array}$} & \multicolumn{3}{|c|}{$\begin{array}{l}\text { Unmet need for family planning } \\
\qquad(\mathrm{N}=304) *\end{array}$} \\
\hline & & $\beta$ & $\mathrm{p}$ & AOR $(95 \% \mathrm{CI})$ & $\beta$ & $\mathrm{p}$ & $\operatorname{AOR}(95 \% \mathrm{CI})$ \\
\hline \multirow[t]{3}{*}{ Age } & $<25$ & & & $1(\mathrm{r})$ & & & \\
\hline & $25-34.9$ & 2.05 & $<0.001$ & $7.7(4.4-13.6)$ & & & \\
\hline & $\geq 35$ & 0.32 & 0.375 & $1.4(0.7-2.8)$ & & & \\
\hline \multirow{3}{*}{$\begin{array}{l}\text { Family } \\
\text { income }\end{array}$} & Enough & & & $1(\mathrm{r})$ & & & $1(\mathrm{r})$ \\
\hline & Not enough & 1.68 & $<0.001$ & $5.4(3-9.7)$ & -2.04 & $<0.001$ & $0.1(0.1-0.3)$ \\
\hline & Save & 1.44 & 0.014 & $4.2(1.3-13.2)$ & -20.6 & 0.998 & 0 \\
\hline \multirow{2}{*}{$\begin{array}{c}\text { No. of living } \\
\text { children }\end{array}$} & 1-2 children & & & $1(\mathrm{r})$ & & & \\
\hline & $>2$ children & 0.86 & 0.004 & $2.4(1.3-4.3)$ & & & \\
\hline \multirow[t]{4}{*}{ Education } & University & & & & & & $1(\mathrm{r})$ \\
\hline & Illiterate/literate & & & & 2.48 & $<0.001$ & $11.9(3.9-37.1)$ \\
\hline & Primary & & & & 1.06 & 0.114 & $2.8(0.8-10.7)$ \\
\hline & Secondary & & & & 1.34 & 0.009 & $3.8(1.4-10.4)$ \\
\hline \multicolumn{2}{|c|}{ Constant } & \multicolumn{3}{|c|}{-1.745} & \multicolumn{3}{|c|}{-1.733} \\
\hline \multicolumn{2}{|c|}{ Model Chi-Square } & \multicolumn{3}{|c|}{$122.65,<0.001$} & \multicolumn{3}{|c|}{$54.459,<0.001$} \\
\hline \multicolumn{2}{|c|}{ Percent correctly predicted } & \multicolumn{3}{|c|}{$73.2 \%$} & \multicolumn{3}{|c|}{$71.5 \%$} \\
\hline
\end{tabular}

$* \mathrm{~N}=304$ because only women aged $\geq 25$ years were included in the analysis, AOR: adjusted Odds Ratio, CI: confidence interval, $r=$ reference group 
Table (5): Maternal satisfaction with family planning (FP) service experience (N=209)

\begin{tabular}{|c|c|c|c|}
\hline \multicolumn{2}{|l|}{ Aspects of FP service satisfaction } & No & Percent \\
\hline \multicolumn{2}{|c|}{ Accessibility of the site of Family Health center providing FP } & 192 & 91.9 \\
\hline \multicolumn{2}{|l|}{ Suitable waiting time } & 190 & 90.9 \\
\hline \multicolumn{2}{|l|}{ Comfortable waiting area } & 204 & 97.6 \\
\hline \multicolumn{2}{|l|}{ Welcoming the woman politely } & 201 & 96.2 \\
\hline \multirow{5}{*}{$\begin{array}{l}\text { Easily understandable information } \\
\text { given during the counseling }\end{array}$} & Yes & 141 & 67.5 \\
\hline & To some extent & 30 & 14.4 \\
\hline & Did not understand & 16 & 7.7 \\
\hline & No information given & 17 & 8.1 \\
\hline & Do not know & 5 & 2.4 \\
\hline \multirow{3}{*}{$\begin{array}{l}\text { Respect of privacy during } \\
\text { counselling and receiving FP } \\
\text { service }\end{array}$} & Yes & 132 & 63.1 \\
\hline & $\mathrm{NO}$ & 52 & 24.9 \\
\hline & I Don't know & 25 & 12.0 \\
\hline \multicolumn{2}{|c|}{ Available educational material (brochures, books...etc.) } & 4 & 1.9 \\
\hline \multicolumn{2}{|l|}{ Respect of woman choice of FP method } & 190 & 90.9 \\
\hline \multicolumn{2}{|l|}{ Affordable price of FP method } & 209 & 100 \\
\hline \multicolumn{2}{|c|}{ Women's preference of the FP method, currently they used } & 207 & 99 \\
\hline \multicolumn{2}{|c|}{ Women were asked if they were satisfied } & 113 & 54.1 \\
\hline
\end{tabular}


العربى الملخص

ممارسة تنظيم الأسرة بين المترددات المتزوجات لوحدة صحة الأسرة في شاوا ، الاقهلية ، مصر

نسرين سعد فر اج ,آية أحمد فتحي ,فريدة عبد الوهاب

الخلفية: يعد الاتصال بفريق الرعاية الصحية فرصة جيدة للتو اصل من أجل التثقف الصحي فيما يتعلق بتنظيم الأسرة و تهدف هذه هذه الدراسة إلى تقدير معدل انتشار استخدام وسائل منع الحمل وانتشار الحاجة غير الملباة بين الإناث الريفيات المترددات على مركز صحة الأسرة فى قرية شاوة بمحافظة الدقهلية. وتحديد العو امل الطريقة والمنهجيه: أجريت در اسة مستعرضة في قرية الثاوة،و اشتملت الدراسة على جميع المترددات المتزوجات غير الحوامل على مركز صحة الأسرة خلال فترة الدراسة، وتم استخدام استبيان لجمع البيانات المتعلقة بالخصائص الاجتماعية_الاقتصادية ، ممارسة تنظيم الأسرة ، الرضا عن الخدمة المقدمة وتم الحصول على عينة مناسبةو نم تحديد مستوى الأهمبة عند 0.05. النتائج: شملت الدر اسة 449 امر أة وكلن معدل استخدام وسائل منع الحمل 46.5\% فى حين كان انتشار الحاجة غير الملباة للحد من الحمل 23.8 ٪ ويظهر الانحدار اللوجستي أن عمر المرأة 25-34.9سنوات ، > 35 سنة، الدخل غير الكافي ، وجود أكثر من طفلين كانت العو امل المستقلة المرتبطة باستخدام أعلى لوسائل منع الحمل، وبين النساء اللواتي تتر اوح أعمار هن بين 25و 35 سنة ازدادت الاحتياجات غير الملباة بشكل ملحوظ بين النساء الأميات، بينما انخفضت بشكل ملحوظ بين النساء ذوات الدخل غير الكافي، و أكثر من 90 في المائة من النساء كن راضين عن معظم جوانب خدمة مع وجود اعتبارات مهمة متعلقة بالخصوصية والاستشارة

الاستتتاجات: ممارسة تنظيم الأسرة بين المترددات يحتاج إلى تحسن كبير. الاحتياجات غير الملباة للحد من الحمل تتعلق بشكل رئيسي بمستوى التعليم المنخفض ـهنالك حاجة على نطاق و اسع لأنشطة المعلو مات و التعليم. 